\title{
ANALISIS PENGENDALIAN BIAYA PROYEK DI PT. PUTRA GEMILANG NIKOM
}

\author{
Oleh : Abu Azhari \\ (PT. KOPPEL MANDIRI BERSAMA)
}

abuazhari10@gmail.com

\begin{abstract}
Abstrak-Penelitian ini merupakan penelitian deskriptif kuantitatif. Penelitian bertujuan untuk mengetahui efektivitas pengendalian biaya proyek di PT. Putra Gemillang Nikom. Objek dalam penelitian ini adalah laporan-laporan atau catatan-catatan tentang anggaran dan realisasi biaya proyek di PT. Putra Gemilang Nikom. Teknik pengumpulan data dalam penelitian ini adalah dokumentasi dan interview (wawancara). Teknik analisis data menggunakan analisis data deskriptif dalam bentuk persentase. Hasil Penelitian menunjukkan bahwa efektivitas pengendalian biaya proyek peningkatan jalan Nikan-Batumarta VIII pada tahun 2015 sebesar 0,95 dan termasuk dalam kategori sangat eektif, tahun 2016 pada proyek peningkatan jalan Gumawang-Petanggan efektivitas pengendalian biaya sebesar 1 dan termasuk dalam kategori efektif, dan pada tahun 2017 proyek peningkatan jalan dalam Kota Muaradua efektivitas pengendalian biaya sebesar 0,94 dan termasuk dalam kategori sangat efektif. Jadi pengendalian biaya proyek di PT. Putra Gemilang Nikom sudah berjalan dengan baik namun masih ada beberapa komponen biaya proyek yang harus di evaluasi pengendaliannya.
\end{abstract}

Kata Kunci : Efektivitas, Pengendalian, Biaya Proyek.

\begin{abstract}
This research is quantitative descriptive. The study aims to determine the effectiveness of project cost control at PT. Son of Gemillang Nikom. The objects in this study are reports or records of the budget and project cost realization at PT. Son of Gemilang Nikom. Data collection techniques in this study are documentation and interviews (interviews). Data analysis techniques using descriptive data analysis in the form of percentages. The results showed that the effectiveness of the cost control project for improving the NikanBatumarta VIII road in 2015 was 0.95 and included in the very eective category, in 2016 the Gumawang-Petanggan road improvement project was cost-effective for 1 and included in the effective category, and in in 2017 the road improvement project in Muaradua City was cost-effective at 0.94 and included in the highly effective category. So controlling project costs at PT. Putra Gemilang Nikom has been going well but there are still several components of the project cost that must be evaluated for its control.
\end{abstract}

Keywords: Effectiveness, Control, Project Cost. 


\section{PENDAHULUAN}

Berdasarkan

efektivitas pengendalian biaya proyek PT. Putra Gemilang Nikom tahun 2015 yaitu 5 $\%, 2016$ yaitu 0,8 \%, 2017 yaitu $6 \%$.

Secara umum efektivitas pengendalian biaya proyek dapat diketahui atau dihitung dengan membandingan anggaran dengan realisasinya. Jadi anggaran yang dibuat merupakan pedoman bagi perusahaan jasa pelaksanaan pembangunan atau kontraktor dalam melaksanakan pembangunan suatu proyek. Dalam kenyataannya bisa saja biaya realisasinya lebih besar dari pada biaya yang telah dianggarkan atau biaya realisasi lebih kecil dari pada biaya yang telah dianggarakan. Bila biaya realisasi lebih besar dari pada anggaran maka secara umum dapat dikatakan telah terjadi pemborosan biaya pada pelaksaan proyek tersebut dan jika biaya realisasinya sama atau lebih kecil dari anggaran maka dapat dikatakan penggunaan biaya dalam pelaksanaan pembangunan proyek tersebut berjalan secara efektif. Selain itu dalam penelitian ini peneliti juga akan meneliti hal-hal yang menyebabkan keberhasilan atau kegagalan PT. Putra Gemilsng Nikom dalam mengendalikan biaya proyek. Seperti pengendalian karyawan, pengendalian keuangan, pengendalian produksi, pengendalian waktu, dan pengendalian teknis.

Menurut Handoko (2015:7) dua konsepsi utama untuk mengukur prestasi kerja (performance) manajemen adalah efisiensi dan efektivitas. Dalam pengendalian ini digunakan satu konsepsi saja yaitu hanya efektivitas, walaupun pada dasarnya kedua konsepsi tersebut saling berkaitan dan tidak bisa dipisahkan satu sama lain antara efisiensi dan efektivitas. Sedangkan menurut Emerson dalam Hasibuan (2011:242) Efektivitas adalah pengukuran dalam arti tercapainya sasaran atau tujuan yang telah ditentukan sebelumnya.

Menurut Peter Drucker dalam Handoko (2015:7) "Efektivitas melakukan pekerjaan yang benar (doing the right things)." Bagi para manajer dan wakil manager, pertanyaan yang paling penting adalah bukan bagaimana menemukan pekerjaan yang benar, tetapi bagaimana menemukan pekerjaan yang benar untuk dilakukan, dan memusatkan sumber daya dan usaha pada pekerjaan tersebut.

Handoko (2015:7) "Efektivitas merupakan kemampuan untuk memilih tujuan yang tepat atau perelatan yang tepat untuk mencapai tujuan yang telah ditetapkan. Dengan kata lain, seorang manajer efektif dapat memilih pekerjaan yang harus dilakukan atau metoda (cara) yang tepat untuk mencapai tujuan".

Sebagai salah satu fungsi dan proses kegiatan dalam manajemen proyek yang sangat mempengaruhi hasil akhir suatu proyek, pengendalian mempunyai tujuan 
utama yaitu meminimalisasikan segala penyimpangan yang dapat terjadi selama proses berlangsungnya pembangunan suatu proyek dan juga bisa menilai apakah suatu pembanguanan proyek itu efektif serta efisien atau tidak sesuai dengan rencana yang telah ditentukan sebelumnya.

Dunia dan Wasilah (2009:5) "Pengendalian merupakan usaha manajemen untuk mencapai tujuan yang telah diterapkan dengan melakukan perbandingan secara terus-menerus antara pelaksanaan dengan rencana". Pengendalian atau pemantauan dilakukan pada waktu program dan kegiatan sedang dilaksanakan. Kegiatan pengendalian ini dilakukan untuk memastikan kesesuaian antara pelaksanaan program dan proyek dengan apa yang telah direncanakan sebelumnya. Dalam hal ini pengendalian yang dimaksud yaitu pengendalian biaya pembangunan proyek agar tidak terjadi penyelewengan keuangan.Menurut Harold Koontz dalam Hasibuan (2011:241) "Pengendalian adalah pengukuran dan perbaikan terhadap pelaksanaan kerja bawahan, agar rencana-rencana yang telah dibuat dapat terlaksana".

Menurut G.R Terry dalam Hasibuan (2011:242) Pengendalian dapat didefinisikan sebagai proses penentuan, apa yang harus dicapai yaitu standar, apa yang sedang dilakukan yaitu pelaksanaan, menilai pelaksanaan dan apabila perlu melakukan perbaikan-perbaikan, sehingga pelaksanaan sesuai dengan rencana-rencana yaitu selaras dengan standar. Berdasarkan beberapa definisi di atas peneliti dapat menyimpulkan pengendalian Sebagai salah satu fungsi dan proses kegiatan dalam manajemen mencapai tujuan yang telah diterapkan dengan melakukan perbandingan secara terus-menerus antara pelaksanaan dengan rencana. Pengendalian membutuhkan standar atau tolak ukur sebagai pembanding, alat ukur kerja dan tindakan koreksi yang akan dilakukan apabila terjadi penyimpangan serta proses pengaturan sebagai faktor berkaitan bisa sesuai dengan apa yang telah direncanakan sebelumnya. saat pelaksanaan, dan setelah pelaksanaan yakni hingga hasil akhir pelaksanaan diketahui. Dengan pengendalian diharapkan juga agar pemanfaatan semua unsur manajemen dilakukan secara efektif dan efisien, agar pelaksanaan proyek tersebut dapat berjalan sesuai dengan rencana yang telah ditetapkan perusahaan serta penggunaan anggaran dan realisasinya bisa efektif sesuai dengan tujuan yang telah ditetapkan perusahaan.

Biaya merupakan komponen penting yang juga mendapat perhatian. Kelangsungan hidup suatu perusahaan ditentukan bagaimana perusahaan mengelola dan mengendalikan biaya-biaya yang ada. Bustami dan Nurlela (2009:7) 
"Biaya atau cost adalah pengorbanan sumber ekonomis yang diukur dalam satuan uang yang telah terjadi atau kemungkinan akan terjadi untuk mencapai tujuan tertentu".

Menurut Sugiri dan riyono (2008:89) "Biaya meliputi semua pengorbanan ekonomik yang dikeluarkan untuk memperoleh pendapatan". Pengorbanan ekonomik dapat berupa penurunan aset atau tambahan kewajiban perusahaan. Dunia dan Wasilah (2012:22) "Biaya (cost) adalah pengeluaranpengeluaran atau nilai pengorbanan memperoleh barang atau jasa yang berguna untuk masa yang akan datang, atau mempunyai manfaat lebih satu periode akuntansi".

Secara umum biaya-biaya proyek menurut Pardede (2007:588) terdiri dari:

a. Biaya langsung (direct cost) adalah seluruh biaya yang dibutuhkan untuk pengadaan bahan-bahan, tenaga kerja, serta biaya-biaya lain yang secara langsung dapat dihubungkan dengan kegiatan-kegiatan proyek dan biaya-biaya langsung terdiri dari biaya normal (normal cost) dan biaya pemercepatan (crashing cost). Biaya-biaya tak langsung (indirect cost) adalah adalah seluruh jenis biaya yang dibutuhkan untuk kegiatankegiatan administrasi serta berbagai biaya umum berubah (variable overhead cost) lain yang jumlahnya dapat diperkecil melalui pengurangan waktu penyelesaian suatu proyek.

b. Biaya-biaya denda adalah (penalty cost) adalah biaya-biaya yang harus dikeluarkan dalam bentuk denda atau hukuman untuk setiap hari keterlambatan penyelesaian suatu proyek.

\section{METODOLOGI PENELITIAN Objek Penelitian}

"Objek penelitian adalah benda, hal, atau orang tempat data untuk variabel penelitian melekat dan yang dipermasalahkan" (Arikunto, 2014:111).Dari pengertian tersebut, maka yang menjadi objek dalam penelitian ini adalah laporan-laporan atau catatan-catatan tentang anggaran dan realisasi biaya proyek di PT. Putra Gemilang Nikom.

Adapun teknik pengumpulan data Menurut Sugiyono (2017:193) bila dilihat dari sumber datanya, maka pengumpulan data dapat menggunakan dua sumber data, yaitu:

a. Data primer adalah sumber data yang langsung memberikan data kepada pengumpul data

b. Data sekunder adalah merupakan sumber yang tidak langsung memberikan data kepada pengumpul data, misalnya lewat orang lain atau dokumen.

Sumber data primer dalam penelitian ini adalah wawancara sedangkan sumber data sekunder adalah tentang anggaran dan realisasi biaya proyek. Dalam suatu penelitian 
terjadi proses pengumpulan datayang bertujuan untuk memperoleh informasi yang selengkaplengkapnya untuk menunjang penelitian. Proses pengumpulan data tersebut dapat dilakukan dengan teknik-teknik tertentu, teknik yang digunakan dalam proses pengumpulan data tergantung pada sifat dan karakteristik yang hendak dilakukan oleh peneliti. Selanjutnya menurut Sugiyono (2017:193) "Bila dilihat dari segi cara atau teknik pengumpulan data, maka teknik pengumpulan data dapat dilakukan dengan observasi (pengematan), interview (wawancara), kuesioner (angket), dokumentasi dan gabungan keempatnya."

Dalam penelitian ini, jadi teknik pengumpulan data yang digunakan dalam penelitian ini, antara lain :

Dokumentasi

$$
\text { Menurut }
$$

Arikunto (2014:274) "Dokumentasi adalah mencari data, mengenai hal-hal atau variabel yang berapa catatan, transkrip, buku, surat kabar, majalah, prasasti, notulen rapat, lengger, agenda, dan sebagainya."

Sedangkan menurut Sugiyono (2017:422):

"Dokumentasi merupakan catatan peristiwa penting yang sudah berlalu. Dokumentasi bisa berbentuk tulisan, gambar, atau karya-karya monumental dari seseorang. Dokumentasi yang berbantuk tulisan misalnya catatan harian, sejarah kehidupan (life histories), ceritera, biografi, peraturan kebijakan. Dokumen yang berbentuk gambar, misalnya foto, gambar hidupm sketsa dan lain-lain. Dokumen yang berbentuk karya misalnya karya seni, yang dapat berupa gambar, patung, film dan lain-lain".

Teknik ini digunakan peneliti untuk mengetahui gambaran umum perusahaan, anggaran biaya, dan realisasi biaya proyek PT. Putra Gemilang Nikom dari tahun 20142017.

Interview (wawancara)

Esterberg (2002) dalam

Sugiyono (2017:410) "mendefinisikan interview sebagai berikut " a meeting of two persons to exchange information and idea through question and responses, resulting in communication and joint contruction of meaning about a particular topic." Wawancara atau interview merupakan pertemuan dua orang untuk bertukar informasi dan ide melalui tanya jawab, sehingga dapat dikonstruksikan dalam suatu topik tertentu.

Menurut Sugiyono (2014:194) "wawancara digunakan sebagai teknik pengumpulan data apabila peneliti ingin melakukan studi pendahuluan untuk menemukan permasalahan yang harus diteliti, tetapi juga apabila peneliti ingin mengetahui hal-hal dari responden yang lebih mendalam. Teknik pengumpulan data ini mendasarkan diri pada laporan tentang diri sendiri atau self-report, atau setidak- 
tidaknya pada pengetahuan dan atau keyakinan pribadi."

Wawancara dilakukan untuk mengumpulkan informasi yang berhubungan dengan pengendalian anggaran dan realisasi biaya proyek PT. Putra Gemilang Nikom. Interview ditujukan kepada manajer keuangan dan pelaksana (pengawas) pelaksanaan anggaran dan realisasi biaya proyek yang digunakan dari tahun 2014-2017. Adapun perihal yang akan ditanyakan yaitu hal-hal yang berkaitan dengan pelaksaan anggaran biaya proyek seperti bahan pekerjaan, upah pekerja, waktu pelaksaan, dan biaya operasional lainnya.

Adapun teknik analisis data yang digunakan dalam penelitian ini adalah analisis data deskriptif dalam bentuk persentase.

a. Analisis Proses Perencanaan dan Pengendalian

Analisis dilakukan dengan menggunakan analisis deskriptif tentang proses perencanaan dan pengenalian yang dilakukan perusahaan, yang pada garis besarnya meliputi, perencanaan, pelaksanaan dan pengendalian atau pengawasan, dengan kata lain, pengerjaan suatu proyek membutuhkan manajemen yang khusus dan hal itu juga digunakan untuk mengetahui cara perencanaan, pengendalian, serta pengawasan anggaran dan realisasi biaya proyek yang digunakan oleh perusahaan tersebut. Selain itu, digunakan untuk mengetahui hambatanhambatan apa saja yang dihadapi perusahaan dalam menyelesaikan suatu proyek.

b. Membandingkan

Antar

Komponen Biaya

$\mathrm{Pi}=\underline{\text { Jumlah Biaya Tiap Komponen }} \times 100$ Jumlah Biaya

Dimana $: \mathrm{Pi}=$ Persentase Setiap Komponen

c. Untuk mengetahui efektivitas pengendalian

d. Biaya proyek digunakan rumus sebagai berikut:

Realisasi x 100\% Rencana

Ukuran yang digunakan sebagai berikut:

$<1$ : sangat efektif

$=1$ : efektif

>1: sangat tidak efektif

(Nadiapaskah, 2012:44)

\section{HASIL DAN PEMBAHASAN Hasil}

Laporan anggaran dan realisasi biaya proyek merupakan hal yang terpenting dalam dunia usaha khususnya pada usaha jasa kontraktor tidak terkecuali PT. Putra Gemilang Nikom, karena laporan anggaran dan realisasi merupakan salah satu kewajiban yang harus dibuat dan disusun oleh manajemen perusahaan. Laporan anggaran dan realisasi PT. Putra Gemilang Nikom yang dianalisis dalam penelitian ini adalah laporan anggaran dan realisasi PT. Putra Gemilang Nikom sebanyak tiga proyek pembangunan jalan dari 
tahun 2015, 2016, dan tahun 2017.

seperti berikut ini:

Yang telah ditetapkan perusahaan

Tabel 1. Laporan Anggaran dan Realisasi Biaya Proyek Peningkatan Jalan Nikan-Batumarta VIII Kecamatan Madang Suku III Kab. Oku Timur PT. Putra Gemilang Nikom Tahun 2015

\begin{tabular}{|c|c|c|c|c|c|}
\hline Y.. & Uraian & Angparan (Rp) & Realinai (Rp) & Effelotinitas & Keteraugan \\
\hline 1 & $\begin{array}{l}\text { BLAYA TENAGA } \\
\text { KFRJA } \\
>\text { Peloerja } \\
>\text { Berub bangeosa } \\
>\text { Pelabeana Pengamas }\end{array}$ & $\begin{array}{l}200.000 .000 \\
\$ 00.000 .000 \\
150.000000\end{array}$ & $\begin{array}{l}200.000 .000 \\
500,000000 \\
150.000000\end{array}$ & $\begin{array}{l}1 \\
1 \\
1\end{array}$ & $\begin{array}{l}\text { Efelufif } \\
\text { Efelofif } \\
\text { Efeloif }\end{array}$ \\
\hline & SUB TOTAL & 350.000 .000 & 850.000 .000 & 1 & Efeleif \\
\hline 2 & $\begin{array}{l}\text { BAFAN BAKU DAN } \\
\text { MATERIAL } \\
>\text { Bahan bangeose }\end{array}$ & 8.475 .000000 & 8.018 .900 .000 & 0.9 & $\begin{array}{l}\text { Sangnit } \\
\text { Efektif }\end{array}$ \\
\hline & SUB TOTAL & 8.475 .000 .000 & 8.018 .900 .000 & 09 & $\begin{array}{l}\text { Sangat } \\
\text { Efektif }\end{array}$ \\
\hline 3 & $\begin{array}{l}\text { BLAYA PERALATAN } \\
\text { DAN OPERASIONAL } \\
>\text { Aloomodasi tesaga } \\
\text { berja }\end{array}$ & $50,000,000$ & 52500,000 & 1,05 & $\begin{array}{l}\text { Sangat Tidalk } \\
\text { Efektiff }\end{array}$ \\
\hline & $>\underset{\substack{\text { proyel } \\
\text { Listr }}}{\text { das air }}$ & $20,000,000$ & 19.700 .000 & 0.99 & $\begin{array}{l}\text { Sangat } \\
\text { Efektif }\end{array}$ \\
\hline & $\begin{array}{l}\text { Transportasi has } \\
\text { bota }\end{array}$ & $30,000,000$ & 30.000 .000 & 1 & Efektif \\
\hline & $>$ Bahan dan alat kerja & 150.000000 & 140.000 .000 & 0.93 & $\begin{array}{l}\text { Sangat } \\
\text { Efelktif }\end{array}$ \\
\hline & $>$ Serra alatberat & 300.000 .000 & 250.000 .000 & 0,83 & $\begin{array}{l}\text { Sangat } \\
\text { Efelitif }\end{array}$ \\
\hline & $>$ BBM & $70,000,000$ & 77.000 .000 & 1,1 & $\begin{array}{c}\text { Sangat Tidalk } \\
\text { Efektiff }\end{array}$ \\
\hline & $>$ Keamanan & $30,000,000$ & 37.000 .000 & 1,23 & $\begin{array}{c}\text { Sangat Tidak } \\
\text { Efektị }\end{array}$ \\
\hline & $>$ Isin-lain & 25.000 .000 & 25.000 .000 & 1 & Efektif \\
\hline & SUB TOTAL & $575,000.000$ & 631.200 .000 & 0,94 & $\begin{array}{l}\text { Sangat } \\
\text { Efektip }\end{array}$ \\
\hline & TOTAL & 10.000 .000 .000 & $9 \$ 00.000 .000$ & 0,95 & $\begin{array}{l}\text { Sangat } \\
\text { Efektif }\end{array}$ \\
\hline
\end{tabular}

(sumber PT Putra Gemilang Nikom)

Berdasarkan tabel 1. didapat total anggaran yang direncanakan sebesar Rp 10.000.000.000 namun yang terealisasi hanya Rp 9.500.000.000.
Berdasarkan tabel 2. didapat total anggaran yang direncanakan sebesar Rp 5.000.000.000 namun yang terealisasi hanya $\mathrm{Rp}$ 4.960.000.000. 
Tabel 2. Laporan Anggaran dan Realisasi Biaya Proyek PeningkatanJalan Gumawang-Petanggan PT. Putra Gemilang Nikom Tahun 2016

\begin{tabular}{|c|c|c|c|c|c|c|}
\hline No & Uraina & Angezaran & Resatisasi & Efelitinitas & Keterang? & \\
\hline \multirow[t]{6}{*}{ 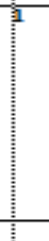 } & $\begin{array}{l}\text { BIAYA } \\
\text { KERJA }\end{array}$ & & & \multirow[b]{2}{*}{1} & \multirow[b]{2}{*}{ Efelktif } & \\
\hline & $>$ Operanos & $110,000,000$ & 110,000000 & & & \\
\hline & $>$ Boroth banguean & 400.000 .000 & 400.000 .000 & 1 & Efelktif & \\
\hline & $>$ Pelabeana Penganas & $100,000,000$ & $100,000,000$ & 1 & Efektifi: & \\
\hline & $>$ Melanex & $95.000,000$ & 95.000000 & 1 & Efelktif: & \\
\hline & SUB TOTAL & 705.000 .000 & 705.000 .000 & 1 & Efelktiff: & \\
\hline \multirow[t]{3}{*}{$\frac{1}{2}$} & $\begin{array}{l}\text { BAFAN BAKT DAN } \\
\text { MATERIAL }\end{array}$ & & & & \multirow{2}{*}{\multicolumn{2}{|c|}{ Efelktif: }} \\
\hline & > Baban bangroan & $3990,000,000$ & 3993.000 .000 & 1 & & \\
\hline & SUB TOTAL & 39900.000 .000 & 3993.000 .000 & 1 & Efektifi: & \\
\hline \multirow[t]{10}{*}{; } & $\begin{array}{l}\text { BLAYA PERALATAN } \\
\text { DAN OPERASTONAI }\end{array}$ & & & & \multirow[b]{2}{*}{ Efektif } & \\
\hline & $\begin{array}{l}\text { Aboomodasi venaga } \\
\text { Lerja }\end{array}$ & $40,000.000$ & 40.000 .000 & 1 & & \\
\hline & $>$ Listrile dan air progele & 15.000 .000 & $15,000.000$ & 1 & Efelktif & \\
\hline & > Tranuportasi hase bota & $30,000,000$ & 32.000 .000 & 1.07 & $\begin{array}{l}\text { Sangat Tid } \\
\text { Efektifi }\end{array}$ & sale \\
\hline & $>$ Baban dan alat Kerja & $100,000,000$ & $\$ 0.000 .000$ & 0.5 & Sangat Efes & stif \\
\hline & $>$ Bensin dan solar & 55.000 .000 & 45.000 .000 & 0.52 & Sangat Efe & tif \\
\hline & $>$ Keamanan & 30,000000 & 30.000 .000 & 1 & Efelktif & \\
\hline & $>$ Lain-lain & 35.000 .000 & 20.000 .000 & 0.57 & Sangat Efeș & stif \\
\hline & SUB TOTAL & $305,000.000$ & 262.000 .000 & 0,55 & Sangat Efọ & iktif \\
\hline & TOTAL & 5.000 .000 .000 & 4960.000 .000 & 1 & Efektifi: & \\
\hline
\end{tabular}

(sumber PT Putra Gemilang Nikom)

Tabel 3. Laporan Anggaran dan Realisasi Biaya Proyek Peningkatan Jalan Dalam Kota Muaradua PT. Putra Gemilang Nikom Tahun 2017

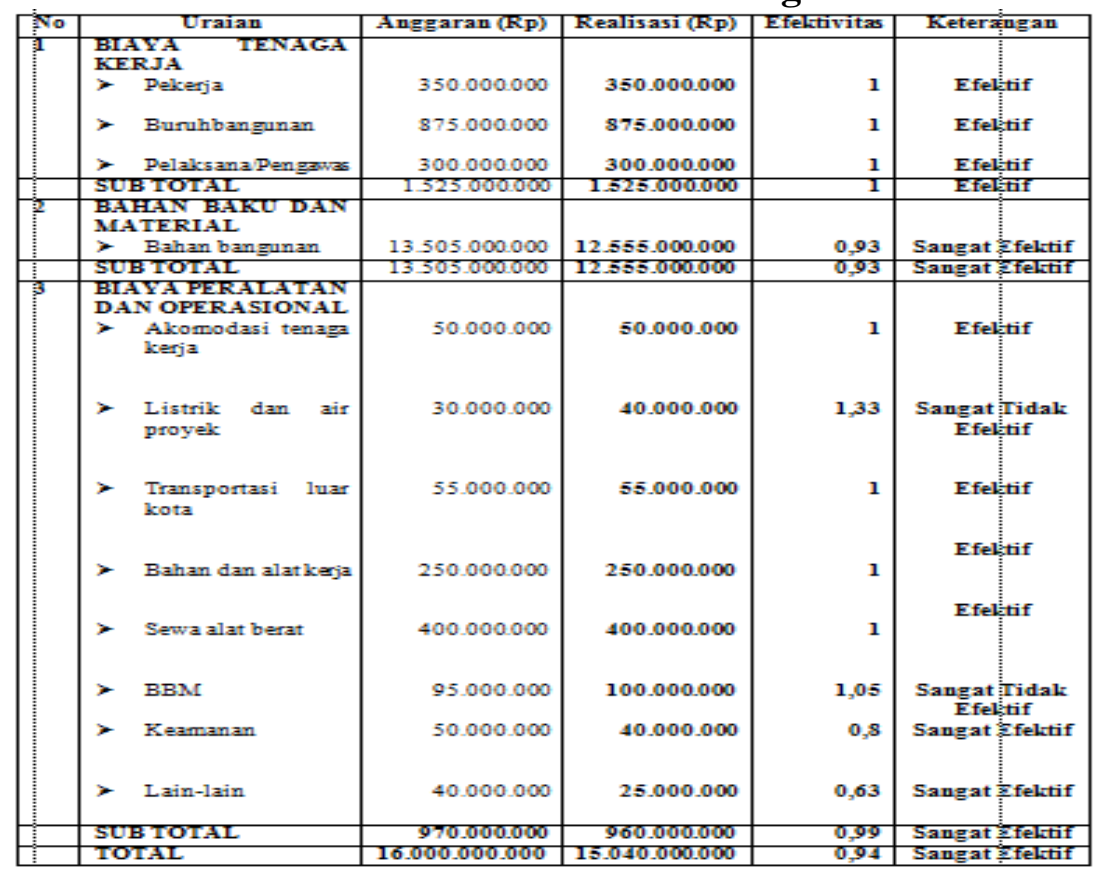

(sumber PT Putra Gemilang Nikom) 
Berdasarkan tabel 3. didapat total anggaran yang direncanakan sebesar Rp 16.000.000.000 namun yang terealisasi hanya Rp 15.040.000.000.

Berdasarkan keterangan dari pejabat PT. Putra Gemilang Nikom yang diwawancarai peneliti dengan wakil direktur utama dan juga bendahara perusahaan ada beberapa faktor yang mempengaruhi keberhasilan dan kegagalan pengendalian komponen-komponen biaya ataupun jenis biaya proyek yang telah dianggarkan. Adapun faktornya sebagai berikut:

1. Manajer proyek

Manajer proyek yang mempunyai jumlah keterampilan dan kemampuan dalam mengendalikan, membimbing anggota tim untuk menyelesaikan semua tujuan sesuai dengan aturan dan ketentuan yang berlaku.

2. Tim pelaksana pembangunan proyek

Tim pelaksana pembangunan proyek harus mempunyai kemampuan dan keterampilan bekerja dengan baik dan bisa bekerja secara tim.

3. Lingkungan eksternal

Dalam hal ini bahwa jenis proyek yang dilaksanakan sangat mempengaruhi keberhasilan ataupun kegagalan. Dalam hal ini yang dimaksud tingkat resiko keberhasilan atau kegagalan, akses proyek, keamanan proyek, struktur geografis proyek.

4. Organisasi

Dukungan manajemen perusahaan merupakan faktor kesuksessan utama dalam melaksanakan pembangunan proyek.

Penyebab keberhasilan pembangunan proyek yang dilakukan oleh PT. Putra Gemilang Nikom karena beberapa faktor yaitu mempunyai tim pelaksana pembangunan proyek yang solid, kemampuan memanfaatkan sumber daya alam yang ada, kemampuan memanfaatkan bahan baku yang ada sehingga tidak terjadinya pemborosan, memperkecil biaya operasional.

Dari hasil penelitian yang dilakukan peneliti pada PT. Putra Gemilang Nikom, diketahui bahwa pengendalian biaya proyek yang digunakan dari tiga proyek tersebut sudah sangat efektif walaupun pada tahun 2016 menurunnya efektivitas biaya yang dikeluarkan. Hal ini sangat wajar terjadi dikarenakan ada beberapa komponen biaya mengalami perubahan atau tidak sesuai dengan yang telah dianggarkan, dan terdapat biaya tambahan yang tidak terduga. Tetapi dalam hal ini efektivitas pengendalian biaya masih digolongkan dalam kategori efektif. Hal ini menimbulkan keuntungan atau laba bagi perusahaan. 
Dari tabel 1. Perhitungan Antar Komponen Biaya Anggaran dan Realisasi Biaya Proyek Peningkatan Jalan Nikan-Batumarta VIII Kecamatan Madang Suku III Kabupaten Oku Timur pada tahun 2015 terlihat bahwa dari ketiga jenis biaya-biaya tersebut yaitu biaya tenaga kerja, biaya bahan baku dan material, dan biaya peralatan dan operasional baik dilihat dari jenis biaya dan komponennya serta total biaya ternyata realisasi ada yang lebih besar dan adapula yang lebi kecil dari anggaran yang telah direncanakan. Sebagai pedoman dalam pelaksanaan pengeluaran biaya pembangunan proyek. Pada jenis biaya tenaga kerja ternyata realisasi biaya sesuai dengan biaya yang telah dianggarkan. Pada jenis biaya bahan baku dan material realisasi diperoleh lebih kecil dibandingkan biaya yang telah dianggarkan dengan efektifitas mencapai 0,9 yang termasuk dalam kategori sangat efektif dari biaya yang telah dianggarkan. Hal ini disebabkan harga bahan baku dan material lebih rendah dari yang telah diperkirakan dan tempat pembelian bahan baku dan material tersebut tidak terlalu jauh sehingga memperkecil ongkos angkut pembelian, serta kemampuan pelaksana dan pekerja di lapangan memanfaatkan bahan baku secukupnya dan tidak berlebihan, sehingga menghemat biaya bahan baku dan material.
Pada jenis biaya peralatan dan operasional jumlah biaya realisasi lebih kecil dari pada biaya yang telah dianggarkan, namun ada beberapa komponen di dalamnya biaya lebih besar dan ada juga lebih kecil dari pada biaya anggaran. Seperti akomodasi tenaga kerja lebih besar 1,05 dan termasuk dalam kategori sangat tidak efektif, hal ini terjadi karena kebutuhan tenaga kerja yang meningkat. Komponen biaya listrik dan air proyek menurun dari biaya yang telah dianggarkan, hal ini dikarenakan penggunaan air tidak terlalu besar dan juga tempat pengambilan air bersumber dari sungai yang ada disekitar lokasi pembangunan. Komponen biaya bahan dan alat kerja lebih kecil dari biaya yang telah dianggarkan karena perusahaan hanya membeli peralatan atau bahan seperlunya dan selebihnya memanfaatkan peralatan atau bahan yang masih ada. Komponen biaya sewa alat berat lebih kecil dari biaya anggaran, hal ini disebabkan perusahaan hanya menyewa alat berat seperlunya dan selebihnya menggunakan alat berat milik perusahaan.

Komponen biaya BBM lebih besar dari anggaran karena meningkatnya intensitas operasional kendaraan dan alat berat. Komponen biaya keamanan meningkat dari biaya anggaran hal ini karena banyaknya keamanan yang harus disewa untuk menjaga keamanan pembangunan proyek seperti polisi, 
tentara, dan keamanan desa. Komponen biaya lain-lain sesuai dengan biaya anggaran.

Dari tabel 2. Perhitungan Antar Komponen Biaya Anggaran dan Realisasi Biaya Proyek Peningkatan Jalan Gumawang-Petanggan pada tahun 2016 terlihat bahwa dari ketiga jenis biaya-biaya tersebut yaitu biaya tenaga kerja, biaya bahan baku dan material, dan biaya peralatan dan operasional baik dilihat dari jenis biaya dan komponennya serta total biaya ternyata realisasi ada yang lebih besar dan adapula yang lebih kecil dari anggaran yang telah direncanakan. Sebagai pedoman dalam pelaksanaan pengeluaran biaya pembangunan proyek. Pada jenis biaya tenaga kerja ternyata realisasi biaya sesuai dengan biaya yang telah dianggarkan. Pada jenis biaya bahan baku dan material realisasi diperoleh lebih besar dibandingkan biaya yang telah dianggarkan. Hal ini disebabkan karena pembelian bahan baku dilakukan di kota dengan jarak tempuh yang cukup jauh sehingga memperbesar biaya bahan bahan baku dan material.

Pada jenis biaya peralatan dan operasional jumlah biaya realisasi lebih kecil dari pada biaya yang telah dianggarkan, namun ada beberapa komponen di dalamnya biaya lebih besar dan ada juga lebih kecil dari pada biaya anggaran. Seperti komponen transportasi luar kota lebih besar dari anggaran hal ini disebabkan ada beberapa kendaraan operasional yang mengalami kerusakan sehingga membutuhkan biaya perbaikan. Komponen biaya bahan dan alat kerja lebih kecil dari biaya yang telah dianggarkan karena perusahaan hanya membeli peralatan atau bahan seperlunya dan selebihnya memanfaatkan peralatan atau bahan yang masih ada. Komponen biaya bensin dan solar lebih kecil dari anggaran hal ini disebabkan tidak terlalu tingginya operasioal kendaraan dan alat berat. Komponen biaya lain-lain lebih kecil dari biaya anggaran hal ini dikarenakan tidak terlalu banyaknya biaya tak terduga yang harus dikeluarkan.

Dari tabel 3. Perhitungan Antar Komponen Biaya Anggaran dan Realisasi Biaya Proyek Peningkatan Jalan dalam Kota Muaradua pada tahun 2017 terlihat bahwa dari ketiga jenis biaya-biaya tersebut yaitu biaya tenaga kerja, biaya bahan baku dan material, dan biaya peralatan dan operasional baik dilihat dari jenis biaya dan komponennya serta total biaya ternyata realisasi ada yang lebih besar dan adapula yang lebi kecil dari anggaran yang telah direncanakan. Sebagai pedoman dalam pelaksanaan pengeluaran biaya pembangunan proyek. Pada jenis biaya tenaga kerja ternyata realisasi biaya sesuai dengan biaya yang telah dianggarkan. Pada jenis biaya bahan baku dan material realisasi diperoleh lebih kecil 
dibandingkan biaya yang telah dianggarkan dengan efektifitas mencapai 0,93 dari biaya yang telah dianggarkan. Hal ini disebabkan tempat pembelian bahan baku dan material tersebut tidak terlalu jauh sehingga memperkecil ongkos angkut pembelian, serta kemampuan pelaksana dan pekerja di lapangan memanfaatkan bahan baku secukupnya dan tidak berlebihan, sehingga menghemat biaya bahan baku dan material.

Pada jenis biaya peralatan dan operasional jumlah biaya realisasi lebih kecil dari pada biaya yang telah dianggarkan, namun ada beberapa komponen di dalamnya biaya lebih besar dan ada juga lebih kecil dari pada biaya anggaran. Seperti komponen biaya listrik dan air proyek meningkat dari biaya yang telah dianggarkan, hal ini dikarenakan jarak tempuh pembelian air yang sangat jauh dan juga pemakaian listrik yang lebih besar. Komponen biaya BBM lebih besar dari anggaran karena meningkatnya intensitas operasional kendaraan dan alat berat. Komponen biaya keamanan lebih kecil dari biaya anggaran hal ini disebabkan tidak teralu banyak keamanan yang harus disewa karena wilayah lokasi pembangunan proyek terbilang cukup aman. Komponen biaya lainlain lebih kecil dari biaya anggaran hal ini dikarenakan tidak terlalu banyaknya biaya tak terduga yang harus dikeluarkan.

\section{KESIMPULAN DAN SARAN}

Berdasarkan hasil penelitian pada PT. Putra Gemilang Nikom maka dapat ditarik suatu kesimpulan bahwa:

1. Efektivitas pada proyek peningkatan jalan NikanBatumarta VIII Kecamatan Madang suku III Kabupaten Oku Timur pada tahun 2015 sebesar 0,95 yang berarti bahwa proyek tersebut dikategorikan dalam proyek sangat efektif, karena realisasi biaya lebih kecil dari anggaran. Adapun jumlah efektivitas pengendaliannya sebesar Rp 500.000.000.

2. Efektivitas pada proyek peningkatan jalan GumawangPetanggan pada tahun 2016 sebesar 1 yang berarti bahwa proyek tersebut dikategorikan dalam proyek efektif, karena realisasi biaya lebih kecil dari anggaran. Adapun jumlah efektivitas pengendaliannya sebesar Rp 40.000.000

3. Efektivitas pada proyek peningkatan jalan dalam Batumarta pada tahun 2017 sebesar 0,94 yang berarti bahwa proyek tersebut dikategorikan dalam proyek sangat efektif, karena realisasi biaya lebih kecil dari anggaran. Adapun jumlah efektivitas pengendaliannya sebesar Rp 960.000.000

Berdasarkan hasil penelitian, maka peneliti memberikan saran sebagai berikut: 
1. Bagi pimpinan perusahaan

Hasil analisis anggaran dan biaya proyek sangat membantu atau penting bagi pimpinan perusahaan dalam mengambil suatu keputusan atau kebijakan. Dari anggaran dan realisasi yang peneliti teliti sudah berjalan sangat baik, pimpinan perusahaan harus terus mempertahankan sistem perencanaan dan pengendalian yang sudah baik dan memperbaiki beberapa komponen biaya yang dianggap melebihi anggaran yang telah ditetapkan.

2. Bagi perusahaan

Manajemen PT. Putra Gemilang Nikom harus lebih cermat dan teliti dalam setiap faktor yang menyebabkan komponen biaya proyek menjadi tidak efektif dan dicari solusinya berdasarkan pengalaman yang ada.

3. Bagi peneliti selanjutnya

Hasil penelitian ini dapat dijadikan sebagai referensi yang relevan dan informasi bagi pihakpihak yang mempunyai kepentingan terutama penelitian yang sejenis di masa mendatang.

\section{UCAPAN TERIMAKASIH}

PT PUTERA GEMILANG NIKOM, atas bantuan dan dukungannya sehingga penelitian ini dapat dilaksakan dengan lancar.

\section{DAFTAR PUSTAKA}

Arikunto, Suharsimi. 2014. Prosedur Penelitian Suatu Pendekata Praktik. Jakarta: Rineka Cipta.
Ahmad \& Wasilah. 2009. Akuntansi

Biaya. Jakarta: Salemba Empat.

Bustami Bastian dan Nurlela, 2009. Akuntansi Biaya, edisi I, Mitra Wacana, Media, Jakarta.

Handoko, T. H. 2015. Manajemen Edisi 2. Yogyakarta: BPFE.

Hasibuan, Malayu S.P. 2011. MANAJEMEN: Dasar, Pengertian, dan Masalah. Jakarta: PT Aksara.

Husen, Abrar. 2009. Manajemen Proyek. Yogyakarta: CV. Andi Offset.

Malue, Jurgen. 2013. Analisis Penerapan Target Costing Sebagai Sistem Pengendalian Biaya Produksi Pada Pt Celebes Mina Pratama. Manado: Jurnal EMBA. Vol. 1, No.3:949-957.

Nadiapaskah. 2012. Analisis Efektivitas Pengendalian Biaya Food And Baverage Departement Pada The Jayakarta Daira Hotel Palembang. Skripi S1 (belum diterbitakan). Pelambang: FE Universitas Sriwijaya.

Pardede, M Pontas. 2007. Manajemen Operasi dan Produksi. Yogyakarta:CV Andi Offset-Yogyakarta.

Pratiwi, Juvita. 2013. Penerapan Biaya Standar Dalam Pengendalian Biaya Produksi Pada Pt. Pertani (Persero) Cabang Sulawesi Utara. Manado: Jurnal EMBA. Vol.1, No.4:1617-1626.

Sudarsana, Dewa Ketut. 2008. Pengendalian Biaya Dan Jadual Terpadu Pada Proyek Konstruksi. Jurnal Ilmiah 
Teknik Sipil Vol. 12, No. 2:117-125.

Sugiri dan Riyono. 2009. Akuntansi Pengantar 1. Yogyakarta: Sekolah Tinggi Ilmu Manajemen YKPN.

Sjafrizal. 2014. Perencanaan Pembangunan Daerah Dalam Era Otonomi. Jakarta: PT Rajagrafindo Persada.

Sugiyono. 2017. Metode Penelitian Pendidikan Pendekatan Kuantitatif,KualitatifDan

$R \& D$. Bandung: Alfabeta.

Nazir, Moh. 2013. Metode Penelitian. Bogor: Ghalia Indonesia. 